\title{
SMALL AND MEDIUM ENTREPRENEURS IN INDONESIA GO GLOBAL: CHALLENGES AND THE PROBLEMS
}

\author{
Evalina \\ Polytechnic LP3I Jakarta \\ evaafzhan06@gmail.com
}

\begin{abstract}
Globalization is representing challenge and opportunity to the international marketer. More integrated countries on a regional basis formed trading block, encourage international trade and investment volume, give consumers choice more products than before. Small and Medium Entrepreneurs (SME) in Indonesia like or not must face the fact, that they must compete with other SME from other countries. But, nowadays most of $S M E$ in Indonesia haven't ready yet to compete with other SME from other countries. This research is analyzed the SME in Indonesia by the power of competition. Can SME in Indonesia face the challenges and problems? How government plays its role to help SME in Indonesia? This research is using qualitative descriptive methods. The results are what the challenges and problems that SME in Indonesia have and how is charges for government role to help the SME in Indonesia.
\end{abstract}

Key Words: Challenges, Globalization, Problems, Small and Medium Entrepreneurs (SME)

\section{INTRODUCTION}

International entrepreneurship or global entrepreneurship specifically examines and prioritizes the role of the entrepreneur as a key factor in the internationalization process of the firm or non-profit organizations (Wach and Wehrmann in Wach, 2014, p. 5).

Thus, research in international entrepreneurship emphasizes the 'human factor'. International entrepreneurship describes internationalization as a "combination of innovative, pro-active, and risk-seeking behavior that crosses national borders and is intended to create value in organizations" (McDougall \& Oviatt, 2000, p. 903). Entrepreneurship done on worldwide basis is known as the global entrepreneurship.
Entrepreneurships and Small and Medium-size Enterprises (SMEs) play a key role in shaping development of a country as they are a source of innovation and economic growth. (Pailis, 2017, p.35). There are numerous studies documenting the nexus between entrepreneurships and SMEs to the country economic growth (Wennekers \& Thurik; Galindo \& Méndez Picazo in Akbar, 2016, p. 2).

Wennekers and Thurik investigated the relationship between entrepreneurship and economic growth using elements of various fields: historical views on entrepreneurship, macro-economic growth theory, industrial economics (Porter's competitive advantage of nations), evolutionary economics, history of economic growth (rise and fall of nations) 
and the management literature on large corporate organizations. The studies found that entrepreneurships contribute to economic performance by introducing innovations, creating changes, creating competition and enhancing rivalry (Wennekers and Thurik in Akbar, 2016, p. 2).

A study of Galindo and Méndez-Picazo (Galindo and Méndez-Picazo, 2013, p. 501) found that innovation playing a central role in the economic growth process and the entrepreneurs are the vehicle to introduce the new technologies to improve the firms' activity and to obtain higher profits. It is also necessary to include in this process other variables: social climate and the role of institutions.

Entrepreneurships have pivotal role in reducing country poverty level particularly in developing countries, for examples Nigeria (Adebayo and Nassar, 2014, p. 1621), India (Goel and Rishi, 2012, p. 45), (Pailis, 2017, p. 31).

Adebayo and Nassar (Adebayo and Nassar, 2014, p. 1621) assessed impact of Micro and Small business entrepreneurship on poverty reduction in Ibadan metropolis, South Western Nigeria. The results suggest that income level of individuals in micro and small business entrepreneurship has increased by 39 per cent.

Goel and Rishi (Goel and Rishi, 2012, p. 45) found that social entrepreneurs help poverty alleviation program in India. The authors also argued that all stakeholders of government, entrepreneurs and citizens have to sit together to eradicate country's poverty level. In Paraguay, Gallardo and Raufflet found that community based entrepreneurships have been successful to alleviate extreme poverty, as they provide opportunities for income generation and capacity enhancement (Gallardo and Raufflet in Akbar, 2016, p. 3).

In Pakistan, Syed et al also found that SMEs has helped country to reduce poverty rate (Syed et al, 2012, p. 137).

\section{LITERATURE REVIEW}

\subsection{Definitions of Micro, Small and Medium Enterprises}

Conceptually a business may assume any of the following sizes:

1. Micro-enterprises

2. Small Scale Enterprises

3. Medium Scale Enterprises and

4. Large Scale Enterprises

According to the UU RI no. 20 Tahun 2008/ The Law no. 20 in 2008, which is called by micro businesses/micro enterprises are entities that have following criteria :

(1) Having net assets not more than Rp. 50.000.000,00 (fifty million rupiahs) excluding the land and the building for businesses; or (2) Having annual sales not more than Rp. 300.000.000,00 (three hundred million rupiahs) which is called by small businesses/small enterprises are entities that have following criteria: (1) Having net assets more than Rp. 50.000.000,00 (fifty million rupiahs) until not more than Rp. 500.000.000,00 (five hundred million rupiahs) excluding the land and the building for businesses; and (2) Having annual sales more than Rp. 300.000.000,00 (three hundreds million rupiahs) until not more than Rp. 2.500.000.000,00 (two billion five hundred million rupiahs).

Meanwhile, which is called medium businesses/medium enterprises are entities that have following criteria: (1) Having net assets more than Rp. 500.000.000,00 (five hundred million rupiahs) until not more than Rp. 10.000.000.000,00 (ten billion rupiahs) excluding the land and the building for businesses; and (2) Having annual sales more than Rp. 2.500.000.000,00 (tua million and five hundred million rupiahs) until not more than Rp. 50.000.000.000,00 (fifty billion rupiahs). 


\subsection{The Theory of Entrepreneur}

\subsubsection{Schumpeter}

Schumpeter (Schumpeter in Zhou, 2012, p. 29) viewed entrepreneurs as innovators who actively create opportunities by recombining information or resources into new products or new methods of production. Schumpeter's entrepreneurs are agents of change that are the source of the creative destruction. They introduce new production processes; they produce new products or produce old products in new ways. Schumpeter's entrepreneurs generate a temporary gap between the price of the inputs and outputs, thereby creating profits for their organizations. The action of the Schumpeter's entrepreneur can be thought of as a process that moves the economic system away from equilibrium. As such, Schumpeter's innovation entrepreneur usually exists in rapidly growing markets and creates new products and services to satisfy future needs.

\subsubsection{Kirzner}

Kirzner (Kirzner in Zhou, 2012, p. 29) emphasized an entrepreneur's ability to identify and exploit gaps in the existing economic system. To exploit an opportunity, a Kirznerian entrepreneur does not innovate, but rather spots pricing inefficiencies that others have missed and thus exploits an information advantage for profit. Entrepreneurs are individuals who spontaneously discover. Kirzner's entrepreneurs discover previously unnoticed profit opportunities in an existing market and capitalize on this imbalance - an act also known as "arbitrage". A Kirznerian entrepreneur focuses on exploiting existing gaps to meet today's needs and makes no longterm impact on economic growth. The action of the Kirznerian entrepreneur moves the economic system towards equilibrium. As such, Schumpeter's alert entrepreneur usually is the strong player in an existing market.

\subsection{Distinctive Characteristics of Born- Global Firms}

Born-global firms possess the following distinctive characteristics (Tanev, 2012, p. 6-7):

1. High activity in international markets from or near the founding

Born-global firms begin exporting their products or services within a couple of years after their founding and may export a quarter or more of their total production. Most of them advance through subsequent stages of internationalization, collaboration with foreign partners, or undertaking of direct foreign investment.

2. Limited financial and tangible resources Born-global firms tend to be relatively small and have far fewer financial, human, and tangible resources as compared to large multinational enterprises that have been considered as dominant in global trade and investment.

3. Present across most industries

Many born-global firms are technology firms. However, recent evidence suggests that the born global phenomenon is widely spread beyond the technology sector (Moen; Rennie in Tanev, 2012, p. 6). For example, in Denmark, Madsen, and Servais have found born global firms in industries such as metal fabrication, furniture, processed food, and consumer products.

4. Managers have a strong international outlook and international entrepreneurial orientation

The managers of born-global firms do not see foreign markets as a mere addition to their domestic markets. They possess a strong entrepreneurial mindset. They proactively and aggressively compete in international markets, they take risks, and innovate.

5. Emphasis on differentiation strategy

Born-global firms tend to adopt differentiation strategies by developing 
differentiated designs and highly distinctive products that target niche markets, which may be too small for the tastes of larger firms. The focus is on stimulating customer loyalty by uniquely meeting particular needs. "People and firms increasingly demand specialized and customized products, and niche markets have become an important source of opportunities for small firms" (Cavusgil and Knight in Tanev, 2012, p. 6).

6. Emphasis on superior product quality Born-global firms are often at the leading technological edge of their industry or product category. They are founded to exploit business opportunities based on the development of new products or services that are better designed and higher quality than competitors' offerings. Typically, these firms do not operate in "commodity" markets (Cavusgil and Knight in Tanev, 2012, p. 6).

7. Leveraging advanced information and communications technology (ICT)

Many born-global firms leverage ICT to segment customers into narrow global-market niches and skillfully serve highly specialized buyer needs. ICT allows them to process information efficiently and communicate with partners and customers worldwide at practically zero cost (Cavusgil and Knight in Tanev, 2012, p. 6).

8. Using external, independent intermediaries for distribution in foreign markets

Most born-global firms expand internationally through exports by engaging in direct international sales or leveraging the resources of independent intermediaries located abroad. Many of them rely on external facilitators to organize international shipments. Exporting and leveraging independent intermediaries enables flexible international operations including the ability to enter or withdraw from foreign markets relatively quickly and easily. More experienced born-global firms appear to adopt additional strategies, such as joint ventures and foreign direct investment (Cavusgil and Knight in Tanev, 2012, p. 6).

\subsection{The Role of Government to Support SMEs}

The central government of China (Zhou, 2012, p. 30) has begun to implement policy changes and new initiatives to maintain economic growth and address the problems described above by helping SMEs go global. As stated by the National Development and Reform Commission: "We will thoroughly implement the 'go global' strategy. We will improve fiscal, taxation, financial and insurance policies to help Chinese enterprises 'go global'. These initiatives are reflected in China's $12^{\text {th }}$ Five-Year Program, which includes five primary missions relating to SMEs:

1. Improve the capacity for establishing business and creating new jobs

2. Optimize the structure of SMEs

3. Boost the development "new, distinctive, specialized and sophisticated" industries and industrial clusters.

4. Upgrade enterprise management levels

5. Refine the service system of SMEs

\section{RESEARCH METHOD}

This research is using qualitative inductive approach. According to Bongdan dan Taylor as quoted by Moleong (2001), qualitative research with the scientific background as the needs to rely on man as research tools, using the qualitative methods and analyzing the data in inductive way. From that statement, provides an illustration that the qualitative study prefer the man as the subject of 
study and more focus on the process than the result.

Through inductive analysis, the research is expressing the meaning of the circumstances that he observed, while to answer the problems theoretically is using the study of literature, with this expected the analysis for some variables will be more accurate.

Connecting a research with the previous relevant research is an effort to find the validity of the research that is reliable and trusted, so to harmonize the research result in order to find the relevancy with the previous research is understanding the explanation.

On the other hand, knowledge of previous research is becoming important as the starting point for the next research. Thus will find new progress in research that can become consideration. (Kemal dan Rossy, 2017, p. 73).

The research subject is using saturated sampling, which is micro, small and medium enterprises in Indonesia.

The kind of data that used was primary and secondary data, through the observation and documentation study. Triangulation of a method being conducted by way of comparing between the observation and the results of documentation study (Rahardjo, 2010, p.1)

\section{RESULT AND DISCUSSION}

Tabel 1. The Progress Of Micro, Small And Medium Enterprise In Indonesia For Year 2009-2013 And Percentage For Progress

\begin{tabular}{|c|c|c|c|c|c|c|}
\hline $\begin{array}{l}\text { NO } \\
\text {. }\end{array}$ & INDICATOR & 2009 & 2010 & 2011 & 2012 & 2013 \\
\hline \multirow[t]{4}{*}{1} & $\begin{array}{l}\text { BUSINESS } \\
\text { UNIT (UNIT) }\end{array}$ & & & & & \\
\hline & $\begin{array}{l}-\quad \text { MICRO } \\
\text { ENTERPRISES }\end{array}$ & $\begin{array}{l}52,176,771 \\
(2.61 \%)\end{array}$ & $\begin{array}{l}53,504,416 \\
(2.54 \%)\end{array}$ & $\begin{array}{l}54,559,969 \\
(1.97 \%)\end{array}$ & $\begin{array}{l}55,856,176 \\
(2.38 \%)\end{array}$ & $\begin{array}{l}57,189,393 \\
(2.39 \%)\end{array}$ \\
\hline & $\begin{array}{l}-\quad \text { SMALL } \\
\text { ENTERPRISES }\end{array}$ & $\begin{array}{l}546,643 \\
(4.70 \%)\end{array}$ & $\begin{array}{l}568,397 \\
(3.98 \%)\end{array}$ & $\begin{array}{l}602,195 \\
(5.95 \%)\end{array}$ & $\begin{array}{l}629,418 \\
(4.52 \%)\end{array}$ & $\begin{array}{l}654,222 \\
(3.94 \%)\end{array}$ \\
\hline & $\begin{array}{l}-\quad \text { MEDIUM } \\
\text { ENTERPRISES }\end{array}$ & $\begin{array}{l}41,336 \\
(4.08 \%)\end{array}$ & $\begin{array}{l}42,008 \\
(1.63 \%)\end{array}$ & $\begin{array}{l}44,280 \\
(5.41 \%)\end{array}$ & $\begin{array}{l}48,997 \\
(10.65 \%)\end{array}$ & $\begin{array}{l}52,106 \\
(6.35 \%)\end{array}$ \\
\hline \multirow[t]{2}{*}{2} & $\begin{array}{l}\text { WORK FORCE } \\
\text { (PERSON) }\end{array}$ & & & & & \\
\hline & $\begin{array}{l}-\quad \text { MICRO } \\
\text { ENTERPRISES }\end{array}$ & $\begin{array}{l}89,960,695 \\
(2.45 \%)\end{array}$ & $\begin{array}{l}91,729,384 \\
(1.97 \%)\end{array}$ & $\begin{array}{l}94,957,797 \\
(3.52 \%)\end{array}$ & $\begin{array}{l}99,859,517 \\
(5.16 \%)\end{array}$ & $\begin{array}{l}104,624,46 \\
6\end{array}$ \\
\hline
\end{tabular}




\begin{tabular}{|c|c|c|c|c|c|c|}
\hline & & & & & & $(4.77 \%)$ \\
\hline & $\begin{array}{l}-\quad \text { SMALL } \\
\text { ENTERPRISES }\end{array}$ & $\begin{array}{l}3,520,497 \\
(0.02 \%)\end{array}$ & $\begin{array}{l}3,768,885 \\
(7.06 \%)\end{array}$ & $\begin{array}{l}3,919,992 \\
(4.01 \%)\end{array}$ & $\begin{array}{l}4,535,970 \\
(15.71 \%)\end{array}$ & $\begin{array}{l}5,570,231 \\
(22.80 \%)\end{array}$ \\
\hline & $\begin{array}{l}-\quad \text { MEDIUM } \\
\text { ENTERPRISES }\end{array}$ & $\begin{array}{l}2,712,431 \\
(0.68 \%)\end{array}$ & $\begin{array}{l}2,740,644 \\
(1.04 \%)\end{array}$ & $\begin{array}{l}2,844,669 \\
(3.80 \%)\end{array}$ & $\begin{array}{l}3,262.023 \\
(14.67 \%)\end{array}$ & $\begin{array}{l}3,949,385 \\
(21.07 \%)\end{array}$ \\
\hline 3 & $\begin{array}{l}\text { THE CURRENT } \\
\text { PRICES BASIS } \\
\text { GDP } \\
\text { (MILLION Rp.) }\end{array}$ & & & & & \\
\hline & $\begin{array}{l}-\quad \text { MICRO } \\
\text { ENTERPRISES }\end{array}$ & $\begin{array}{l}1,747,339.0 \\
0 \\
(15.71 \%)\end{array}$ & $\begin{array}{l}2,011,544.2 \\
0 \\
(15.12 \%)\end{array}$ & $\begin{array}{l}2,579,388.4 \\
0 \\
(28.23 \%)\end{array}$ & $\begin{array}{l}2,951,120.6 \\
0 \\
(14.41 \%)\end{array}$ & $\begin{array}{l}3,326,564.8 \\
0 \\
(12.72 \%)\end{array}$ \\
\hline & $\begin{array}{l}-\quad \text { SMALL } \\
\text { ENTERPRISES }\end{array}$ & $\begin{array}{l}517,919.70 \\
(9.54 \%)\end{array}$ & $\begin{array}{l}596,884.40 \\
(15.25 \%)\end{array}$ & $\begin{array}{l}740,271.30 \\
(24.02 \%)\end{array}$ & $\begin{array}{l}798,122.20 \\
(7.81 \%)\end{array}$ & $\begin{array}{l}876,385.30 \\
(9.81 \%)\end{array}$ \\
\hline & $\begin{array}{l}-\quad \text { MEDIUM } \\
\text { ENTERPRISES }\end{array}$ & $\begin{array}{l}704,087.50 \\
(11.70 \%)\end{array}$ & $\begin{array}{l}803,146.00 \\
(14.07 \%)\end{array}$ & $\begin{array}{l}1,002,170.3 \\
0 \\
(24.78 \%)\end{array}$ & $\begin{array}{l}1,120,325.3 \\
0 \\
(11.79 \%)\end{array}$ & $\begin{array}{l}1,237,057.8 \\
0 \\
(10.42 \%)\end{array}$ \\
\hline 4 & $\begin{array}{lrr}\text { THE } & \text { TOTAL } \\
\text { EXPORT OF } \\
\text { NON OIL \& } \\
\text { GAS } \\
\text { (MILLION Rp.) }\end{array}$ & & & & & \\
\hline & $\begin{array}{l}-\quad \text { MICRO } \\
\text { ENTERPRISES }\end{array}$ & $\begin{array}{l}14,375.30 \\
(-12.69 \%)\end{array}$ & $\begin{array}{l}16,687.50 \\
(16.08 \%)\end{array}$ & $\begin{array}{l}17,249.30 \\
(3.37 \%)\end{array}$ & $\begin{array}{l}15,235.20 \\
(-11.68 \%)\end{array}$ & $\begin{array}{l}15,989.50 \\
(4.95 \%)\end{array}$ \\
\hline & $\begin{array}{l}-\quad \text { SMALL } \\
\text { ENTERPRISES }\end{array}$ & $\begin{array}{l}36,839.70 \\
(-8.04 \%)\end{array}$ & $\begin{array}{l}38,001.00 \\
(3.15 \%)\end{array}$ & $\begin{array}{l}39,311.70 \\
(3.45 \%)\end{array}$ & $\begin{array}{l}32,508.80 \\
(-17.31 \%)\end{array}$ & $\begin{array}{l}32,051.80 \\
(-1.41 \%)\end{array}$ \\
\hline & $\begin{array}{l}-\quad \text { MEDIUM } \\
\text { ENTERPRISES }\end{array}$ & $\begin{array}{l}111,039.60 \\
(-8.60 \%)\end{array}$ & $\begin{array}{l}121,206.40 \\
(9.16 \%)\end{array}$ & $\begin{array}{l}130,880.80 \\
(7.98 \%)\end{array}$ & $\begin{array}{l}118,882.40 \\
(-9.17 \%)\end{array}$ & $\begin{array}{l}134,071.40 \\
(12.78 \%)\end{array}$ \\
\hline
\end{tabular}

Source : www.Depkop.co.id

When the global financial crisis began in 2008, the situation in Indonesia also began to change. As world stock markets fell, large financial institutions collapsed 
(or were bailed out) and a European debt crisis developed. Global manufacturing demand fell, causing decline in Indonesia's export growth, as micro enterprises $(-12,69 \%)$, small enterprises $(-8,04 \%)$ and medium enterprises ($8,60 \%)$.

During the 2008-2009 global downturn economic growth in Indonesia slowed only moderately (Elias and Clare Noone, 2011, p. 33), the business units, workforce and the GDP are still increasing, although the increasing are small enough.

From the data in table 1 , the progress of business units (SMES) from 2009 until 2013 are always increasing. The increasing is varieties between $1,97 \%$ in 2011 until 2,61\% in 2009 for micro enterprises. For the increasing small enterprises are varieties between $3.94 \%$ in 2013 until 5,95\% in 2011. And for the increasing medium enterprises are varieties between $1.63 \%$ in 2010 until $10,65 \%$ in 2012.

But for the increasing of workforce are not the same with the increasing business units. The increasing is varieties between $1,97 \%$ in 2010 until $5,16 \%$ in 2012 for micro enterprises. For the increasing small enterprises are varieties between $0,02 \%$ in 2009 until $22,80 \%$ in 2013 . And for the increasing medium enterprises are varieties between $0,68 \%$ in 2009 until $21,07 \%$ in 2013.

The increasing of total export of nonoil and gas for SMES are more minus than plus especially for medium enterprises are minus for the year $2009(-8,04 \%), 2012$ ($17,31 \%)$ and $2013(-1,41 \%)$. But, for the micro and medium enterprise are minus for the year 2009, each $(-12.69 \%)$ and ($8.60 \%)$, and for year 2012, each ($11,68 \%)$ and $(-9,17 \%)$.

As comparation the condition between China and Indonesia: in 2009, 42 million SMEs in China contributed to $58.5 \%$ of GDP, $68 \%$ of exports, and $75 \%$ of new employment (Zhou, 2012, p. 28) compare with the SMEs in Indonesia, 52,7 million SMEs in Indonesia $(99,99 \%$ from the total enterprise) only contributed to $56,18 \%$ of GDP, $17,02 \%$ of exports non-oil and gas, but they hire $97,28 \%$ of new employment (a big percentage of all new employment). It can be compared with big enterprise in Indonesia; 4,67 million (1\%) big enterprise contributed to $43,18 \%$ of GDP, $82,98 \%$ of exports non-oil and gas, but they participated in hire new employment only $2,72 \%$.

It can be seen the SMEs in Indonesia are low productive in GDP, only contributed a small portion in total export, but almost hire all of new employment, so the value added for workforce in SMEs are very low (Lestari in Sarwoko, 2008, p. 227).

Table 2. The Fact About Indonesia Ahead of Free Trade in 2015

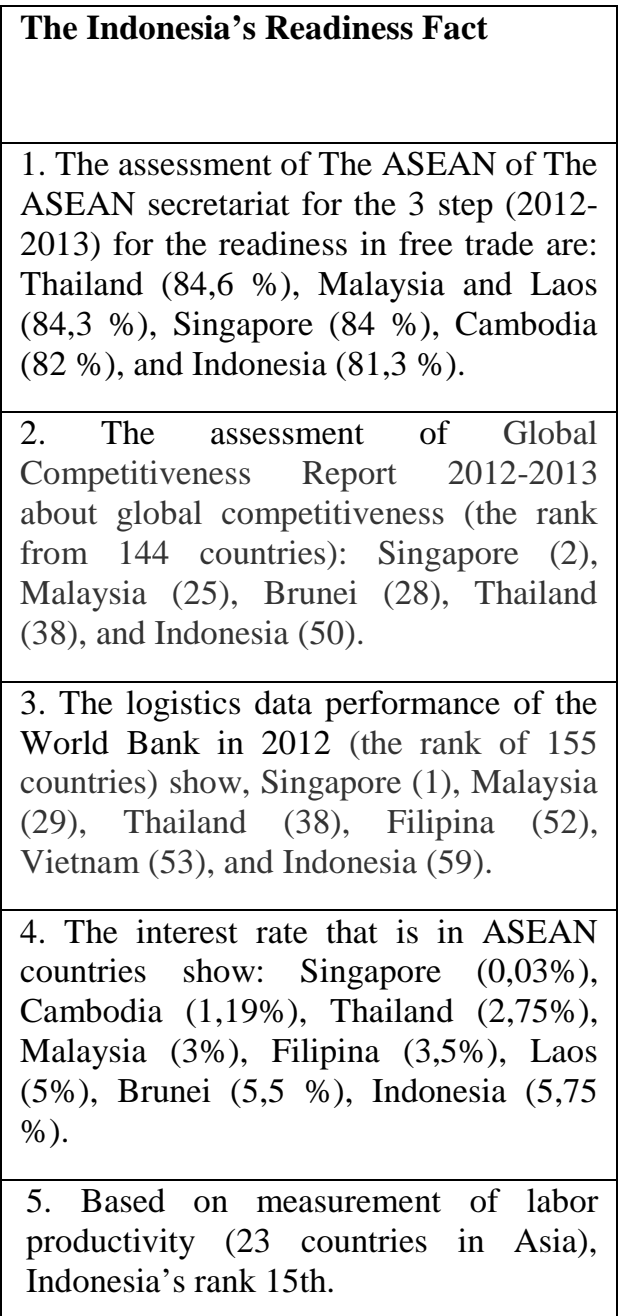


6. Based on research is only about $12 \%$ from all the work force in Indonesia has a college graduate standard.

Source : Republika.com in Meliala et al, 2014, p. 643

Based on this condition, what are challenges and the problems for SMEs in Indonesia going global?

The Challenges and The Problems for SMEs Indonesia go global based on Distinctive Characteristics by Tanev (Tanev, 2012, p. 6-7):

1. High activity in international markets from or near the founding

Born-global firms begin exporting their products or services within a couple of years after their founding and may export a quarter or more of their total production.

a. The challenges for SMEs in Indonesia are making goal to export their products in compare with the Indonesia readiness in free trade $81,3 \%$ as. The assessment of The ASEAN secretariat.

b. The problems for SMEs to export their products are :

1). People who are involved in many highly qualified SMEs yet reliable and Professional, especially also in the field of entrepreneurship. (Machmud dan Iwan Sidharta, 2014, p. 55)

2). Limitations of local labor and skills of trained human resources in the field of SMEs resulting limitation management, marketing, capital, partnership and technology.

3).The Weak of Management Mastery.

Equal to previous studies, we find that the absence of the application of fundamental principle of good management, as production management (especially quality control), capital management and marketing (to get the consumers). (Wajdi, 2005, p. 148-149), (Graha, 2011 , p. 3). The rank of labor productivity of Indonesia is $15^{\text {th }}$ from 23 countries in Asia, the rank of readiness for free trade Indonesia is $81,3 \%$. (Republika.com in Meliala et al, 2014, p. 643).

4).The Lack of Copyright Protection.

This has resulted the weakness of enterprise position abroad, especially if the entrepreneurs want to export their products.

5).The Non effective the Role of Government.

The ineffectiveness of government policy because of a lack of appropriate for the condition and the needs of the small enterprise/industry entrepreneurs.

2. Limited financial and tangible resources

Born-global firms tend to be relatively small and have far fewer financial, human, and tangible resources as compared to large multinational enterprises that have been considered as dominant in global trade and investment.

a. The challenges for SMEs in Indonesia are making efficient and effective enterprises in order go global with limited financial and tangible resources.

b. The problems for SMEs in making efficient and effective enterprises with limited financial and tangible resources are :

There has been no financial administration, the weak of management mastery, the limitations of local labor and skills of trained human resources. (Wajdi, 2005, p. 148-149), (Machmud dan Iwan Sidharta, 2014, p. 55), (Graha, 2011, p.3). The rank of Indonesia is $59^{\text {th }}$ from 155 countries for logistic data 
performance, the highest interest rate from all of ASEAN countries (Republika.com in Meliala et al, 2014, p. 643).

3. Present across most industries Many born-global firms are technology firms. However, recent evidence suggests that the born global phenomenon is widely spread beyond the technology sector.

a. The challenges for SMEs in Indonesia are making goal to export their products, because nowadays born-global firms are not only technology firms, spread beyond the technology sector.

b. The problems for SMEs in making goal to export their products are: the lack of copyright protection, the lack of skill of production technology and product quality, the lack of innovation, the limited use of information technology to promote SMEs, the lack of government support. (Wajdi, 2005, p. 148-149), (Machmud dan Iwan Sidharta, 2014, p. 5556), (Graha, 2011, p.3), the rank of readiness for free trade Indonesia is $81,3 \%$. (Republika.com in Meliala et al, 2014, p. 643).

4. Managers have a strong international outlook and international entrepreneurial orientation

The managers of born-global firms do not see foreign markets as a mere addition to their domestic markets. They possess a strong entrepreneurial mindset.

a. The challenges for SMEs in Indonesia are having managers who have strong international outlook and international orientation who can encourage the growth the exporter SMEs.

b. The problems for SMEs in having who have strong international outlook and international orientation are: the limitations of local labor and skills of trained human resources, the weakness of entrepreneurs as personal, (Wajdi, 2005, p. 148-149), (Machmud dan Iwan Sidharta, 2014, p. 55-56), (Graha, 2011, p.3), (Tambunan pada Wajdi, 2005, p. 141), the rank of Indonesia in global competitiveness is 50th from 144 countries, only $12 \%$ from all the work force in Indonesia has a college graduate standard (Republika.com in Meliala et al, 2014, p. 643).

5. Emphasis on differentiation strategy Born-global firms tend to adopt differentiation strategies by developing differentiated designs and highly distinctive products that target niche markets, which may be too small for the tastes of larger firms.

a. The challenges for SMEs in Indonesia are implementing differentiation strategy by developing differentiated designs and highly distinctive products that target niche markets.

b. The problems for SMEs in implementing differentiation strategy by developing differentiated designs and highly distinctive products that target niche markets are : The weak of management mastery, 3. Most of raw materials need still come from outside or imported, the lack of skill of production technology and product quality, the lack of innovation, the limited use of information technology to promote SMEs, the limitation of capital, the ability and the aggressiveness of the SMEs entrepreneurs to access markets is still limited, the financial administration and management system is not too good SMES and lack of data and information that is sharp. (Lestari in Sarwoko, 2008, p. 227), (Wajdi, 2005, p. 
148-149), (Machmud dan Iwan Sidharta, 2014, p. 55-56), (Graha, 2011 , p.3), the rank of readiness for free trade Indonesia is $81,3 \%$. (Republika.com in Meliala et al, 2014, p. 643).

6. Emphasis on superior product quality

Born-global firms are often at the leading technological edge of their industry or product category. They are founded to exploit business opportunities based on the development of new products or services that are better designed and higher quality than competitors' offerings.

a. The challenges for SMEs in Indonesia are emphasis on superior product quality by developing of new products or services that are better designed and higher quality than competitors' offerings.

b. The problems for SMEs in emphasis on superior product quality are: the lack of innovations, the limitations of local labor and skills of trained human resources, limitation management, marketing, capital, partnership and technology, limitation skill of production technology and product quality, limitation use of information technology to promote SMEs product, limitation of capital capability, entrepreneurs in general are still not able to meet the market demand requires the stability of quality, a large number of orders, fast and timely delivery. (Lestari in Sarwoko, 2008, p. 227), (Graha, 2011, p.3), (Wajdi, 2005, p. 148-149), (Machmud dan Iwan Sidharta, 2014, p. 55). the rank of global for competitiveness for Indonesia is $50^{\text {th }}$ from 144 countries. (Republika.com in Meliala et al, 2014, p. 643).
7. Leveraging advanced information and communications technology (ICT) Many born-global firms leverage ICT to segment customers into narrow global-market niches and skillfully serve highly specialized buyer needs.

a. The challenges for SMEs in Indonesia are leveraging advanced information and communications technology (ICT) to segment customers into narrow flobalmarket niches and skillfully serve highly specialized buyer needs.

b. The problems for SMEs in leveraging advanced information and communications technology (ICT) are: lack of data and information that is sharp and up to date of SMEs are ready to be marketed (Machmud dan Iwan Sidharta, 2014, p. 55) and lack of information and communications technology.

8. Using external, independent intermediaries for distribution in foreign markets

Most born-global firms expand internationally through exports by engaging in direct international sales or leveraging the resources of independent intermediaries located abroad.

a. The challenges for SMEs in Indonesia are using external, independent intermediaries for distribution in foreign markets to expand internationally through exports.

b. The problems for SMEs in using external, independent intermediaries for distribution in foreign markets to expand internationally through exports are: ability to capital is limited, the lack of business network, the use of modern technology (Machmud dan Iwan Sidharta, 2014, p. 55-56), the weakness of entrepreneurs as personal 
(Tambunan pada Wajdi, 2005, p. 141), the limitation access to the banking (Graha, 2011, p.3).

\section{CONCLUSION}

The study has identified the challenges and problems that SMEs in Indonesia face to go global. Several expectations from the SMEs to ease the facilities from the government and private :

1. The trained and educated human resource who can help SMEs go global. Government and private party can give the program that has SMEs go global objective.

\section{REFERENCES}

Adebayo, N. A., \& Nassar, M. L. (2014). Impact of micro and small business entrepreneurship on poverty reduction in Ibadan metropolis, South Western Nigeria. International Review of Management and Business Research, 3 (3), 1603-1626.

Akbar, Riznaldi. (2016). An Investigation of Determinants Global Entrepreneurship: Multi-Country Panel Studies. DeReMa Jurnal Manajemen. 11(1), 1-14.

Elias, Stephen and Clare Noone. (2011). The Growth and Development of The Indonesian Economy. Reserve Bank of Australia Bulletin, December Quarter, 33-43.

Goel, G., \& Rishi, M. (2012). Promoting entrepreneurship to alleviate poverty in India: An overview of government schemes, private-sector programs, and initiatives in the citizens sector. Thunderbird International Business Review, 54 (1), 45-57.

Graha, Andi Nu. (2011). Peranan UKM Menjalin Kemitraan Guna
2. Sustainable development for SMEs in license maintain, brand protection, copyright protection, export license, funding and marketing help in order SMEs can go global.

3. The ease of export tax and export process.

4. The ease of logistics procurement, the stabilization of the price of raw materials and guarantees the availability of getting raw materials. .

5. The standard of charges that SMEs must be paid. (Meliala et al, 2014. P. 653).
Memperluas Jaringan, Pengembangan Media dan Sarana Berbisnis. Modernisasi, 7(1), 1-23.

Kemal, Isthifa, Rossy Angelia Hasibuan. (2017). Manajeman Kewirausahaan melalui Strategi Berbasis Sekolah di Islamic Solidarity School. Jurnal Akuntabilitas Manajemen Pendidikan. 5(10), 71-81.

Machmud, Senen dan Iwan Sidharta. (2014). Business Models for SME in Bandung: SWOT Analysis. Jurnal Ekonomi, Bisnis \& Entrepreneurhsip, 8(1), 51-61.

Meliala, Andi Suranta, Nazaruddin Matondang and Rahmi M. Sari. (2014). Strategi Peningkatan Daya Saubg Usaha Kecil dan Menengah (UKM) Berbasis Kaizen. Jurnal Optimasi Sistem Industri, 13(2), 641-664.

McDougall, P.P, \& Oviatt, B.M. (2000). International Entrepreneurship: The Intersection of Two Research Paths. The Academy of Management Journal, 43(5), 902-906.

Galindo, Miguel Ángel, and María Teresa Méndez Picazo. (2013). Innovation, 
entrepreneurship and economic growth. Management Decision, 51 (3), 501-514.

Moleong, L. J. (2001). Metode Penelitian Kualitatif. Bandung: PT. Remaja Rosda Karya

Pailis, Eka Armas. (2017). Analisis Pengembangan Wirausaha Lokal Melalui Sektor Ekonomi Basis Industri Kecil Menengah (IKM) di Kabuapaten Kampar. Jurnal Ilmiah Ekonomi dan Bisnis, 14 (1), 31-44.

Rahardjo, Mudjia. (2010). Triangulasi dalam Penelitian Kualitatif. Diperoleh tanggal 8 Januari 2017. Dari http://www.uinmalang.ac.id/r/101001/triangulasidalam-penelitian-kualitatif.html

Sarwoko, Endi. (2008). Kajian FaktorFaktor Penentu Keberhasilan Small Business. Modernisasi, 4(3), 226239.

Syed, A. A. G., Shah, N., Shaikh, K. H., Ahmadani, M. M., \& Shaikh, F. M. (2012). Impact of SMEs on employment in textile industry of Pakistan. Asian Social Science, 8 (4), 131-142.
Tanev, Stoyan. (2012). Global From The Start: The Characteristics of Born Global Firms in The Technology Sector. Technology Innovation Management Review. 5-8

UU RI No. 20 Tahun 2008 Tentang Usaha Mikro, Kecil dan Menengah

Wach, Krzysztof. (2014). Editorial: Global Entrepreneurship from the European Perspective. Entrepreneurial Business and Economics Review, 2(1), 5-6

Wajdi, M. Farid. (2005). Dinamika Sentra Industri Kecil Menuju Era Perdagangan Bebas. Benefit, 9(2), 140-152.

Zhou, Daniel. (2012). Chinese Entrepreneurs Go Global. Technology Innovation Management Review, Technology Entrepreneurship, 28-31. 